UDC 94(477.82):37(091)(477)"1917/1920"

DOI: $10.24919 / 2519-058 x .17 .218189$

\title{
Oksana KALISHCHUK
}

PhD hab. (History), Professor, Professor of Department of Archaeology, Ukraine's History of Lesya Ukrainka Eastern European National University, 24 Shopena Street, Lutsk, Ukraine, postal code 43000 (kaliszczuk.oksana@gmail.com)

ORCID: 0000-0003-1272-7920

ResearcherID: E-4566-2019

\section{Оксана КАЛІЩУК}

доктор історичнихнаук, професор, професор кафедри археології, давньоїта середньовічної історії Украӥни Східноєвропейського національного університету імені Лесі Украӥнки, вул. Шопена, 24, м. Луцьк, Україна, індекс 43000 (kaliszczuk.oksana@gmail.com)

Bibliographic Description of the Article: Kalishchuk, O. (2020). Volyn during World War I: cultural, educational aspects through the prism of prosopography. Skhidnoievropeiskyi Istorychnyi Visnyk [East European Historical Bulletin], 17, 101-111. doi: 10.24919/2519-058x.17.218189

\section{VOLYN DURING WORLD WAR I: CULTURAL, EDUCATIONAL ASPECTS THROUGH THE PRISM OF PROSOPOGRAPHY}

\begin{abstract}
The Purpose of the Research is to characterize the prosopographic aspect of cultural, educational activities of the Ukrainian military and public structures in Western Volyn during World War I and to clarify the role of individual representatives of the Galician and local (Volyn) intelligentsia in the national life of the region. The Methodology of the Research was formed by the principles of historicism, systematization, general scientific methods of logics, an authorial objectivity, special historical methods (a historiographical analysis, a historical systemic method, a chronology method, a historical genetic method. The scientific novelty consists in the task to characterize the cultural, educational activities of Ukrainian military and public structures in Western Volyn during World War I and to clarify the role of individual representatives of the Galician, Naddniprianska and local (Volyn) intelligentsia in the national life of the region. The Conclusions. The peculiarity of the legion of Ukrainian Sich Riflemen was its activity not only as an armed formation at the fronts of World War I, but also as a factor in the Ukrainian national movement. One of the tasks set by the USS (the USS - Ukrainian Sich Riflemen) was a national self-awareness both among the Sich members themselves and among the Ukrainians of the areas, where the Sich members fought during the hostilities. The national self-awareness was facilitated by the presence of prominent intelligentsia representatives. Owing to their efforts Volyn succeeded in the cultural and educational spheres in 1916 - 1918. The delegated Sich riflemen became selfless organizers of a socio-political life in the region and bearers of the Ukrainian national idea. The selfless work of the Galicians and residents of Naddniprianshchyna, such as: D. Vitovsky, M. Havrylko, M. Saevych, S. Sydorovych, I. Krypiakevych and the others, became the basis for the growth of the Ukrainian movement in Volyn during the interwar period and World War II.

Key words: Ukrainian Sich Riflemen, Volyn, cultural and educational movement, Ukrainian schooling.
\end{abstract}




\title{
ВОЛИНЬ У РОКИ ПЕРШОЇ СВІТОВОЇ ВІЙНИ: КУЛЬТУРНО-ОСВІТНІЙ АСПЕКТ КРІЗЬ ПРИЗМУ ПРОСОПОГРАФІЇ
}

\begin{abstract}
Анотація. Метою дослідження є охарактеризувати просопографічний аспект культурноосвітньої та просвітницької діяльності украӥнських мілітарних і громадських структур на Західній Волині у роки Периої світової війни та з'ясувати роль окремих представників галицької та місиевої (волинської) інтелігенції у національному жсттті регіону. Методологію дослідження сформували принципи історизму, системності, загальнонаукові методи логіки, авторської об'єктивності, спеціально-історичні методи (історіографічного аналізу, історико-системний, хронологї, історико-генетичний). Наукова новизна полягає у тому, щзо вперие проаналізовано культурно-освітню та просвітницьку діяльність українських мілітарних і громадських структур на Західній Волині у роки Периої світової війни та з 'ясувати роль окремих представників галицької, наддніпрянської й місиевої (волинської) інтелігенції у національному житті регіону. Висновки. Особливістю легіону Украӥнських січових стрільців стала його активність не лише як збройного формування на фронтах Першої світової війни, а й як чинника украӥнського національного руху. Одним із завдань, яке ставили перед собою усуси, - національне самоусвідомлення і серед самих січовиків, і серед україниів тих теренів, куди вони потрапляли у ході воєнних дій. Цьому сприяла присутність яскравих представників інтелігенції. Саме завдяки їх зусиллям 1916 - 1918 рр. на Волині вдалося досягнути успіхів у культурно-освітній сфері. Делеговані січові стрільизі стали самовідданими організаторами суспільно-політичного життя в краї та носіями української національної ідеї. Самовіддана прачя галичан та наддніпряниів Д. Вітовського, М. Гаврилка, М. Саєвича, С. Сидорович, I. Крип'якевича та інших стала підгрунтям зростання украӥнського руху на Волині у міжвоєнний період та у роки Другої світової війни.

Ключові слова: Украӥнські січові стрільці, Волинь, культурно-освітній рух, украӥнське икільництво.
\end{abstract}

The Problem Statement. World War I became the geopolitical turning point, which changed the fate of the states and nations. As Olexander Reyent expressed it figuratively: "World War I opened in the XXth century "Pandora's box" of new horrors and terrible trials for the population of the countries, which were at war" (Reient, 2016). It marked the era of wars, revolutions, national liberation movements, which lasted for almost the entire XXth century. As paradoxical as it may sound at first glance, the Great War intensified the national and cultural life of the peoples of Central and Eastern Europe. Ukraine, in general, and Volyn, in particular, did not stay away from these processes. These areas were primarily related to the activities of the Sich Riflemen Legion.

The study of the national self-awareness forms, the development patterns of a national education under military conditions remains relevant for Ukrainian science and society even nowadays. The use of the experience of World War I under conditions of the modern Ukrainian-Russian hybrid war actualizes such studies not only in the theoretical but also in practical plane.

The Analysis of Recent Researches. The first information, and later research on the activities of the USS, is known to be found in the works of such Ukrainian historians and intellectuals, who were directly or indirectly connected with the Ukrainian Sich Riflemen, as I. Krypiakevych, D. Doroshenko, K. Levytsky. After the period of absence of this issue in the Soviet historical science, with the independence of Ukraine, the cultural, educational work of the riflemen formations in Volyn was analyzed by M. Bahriy (Bahrii, 2018), L. Bashniak (Bashniak, 2009), V. Bernadsky (Bernadskyi, 1995; Bernadskyi, 2012), H. Haidukevych (Haidukevych, 2005), O. Demyaniuk (Demianiuk, 2015; Demianiuk, 2007; Demianiuk, 2017), O. Kalishchuk (Kalishchuk, 2000; Kalishchuk, 2016), T. Kuzmenko (Kuzmenko, 2005), 
M. Lazarovych (Lazarovych, 2003; Lazarovych, 2016a; Lazarovych, 2016б), P. Lepisevych (Lepisevych, 2003), M. Lytvyn and K. Naumenko (Lytvyn, 1990), I. Pater (Pater, 1996; Pater, 1998), O. and S. Soloviovy (Soloviov, 1996). B. Zabrovarny (Zabrovarnyi, 1996), O. Kalishchuk (Kalishchuk, 2016), N. Klymenko (Klymenko, 2007), O. Rudenko (Rudenko, 2017), R. Fabryka (Fabryka, 1998) analyzed prosopography of the topic. Therefore, accoding to the research by V. Velykochyi, we state that for more than nine decades a considerable literature on the history of the Ukrainian riflemen has been accumulated and, at the same time, despite a considerable scientific interest, this history has gaps and perspective areas of the research (Velykochyi, 2012, p. 23). In our opinion, the topic of the activities of the USS in Volyn belongs to these reseaches.

The purpose of the article is to characterize the cultural, educational activities of the Ukrainian military and public structures in Western Volyn during World War I and to clarify the role of individual representatives of the Galician and local (Volyn) intelligentsia in the national life of the region.

The Statement of the Basic Material. In the summer of 1915, the Austro-Hungarian troops occupied Kovel, Volodymyr-Volynsky, Lutsk, and partly Kremenets, Dubno, and Rivne counties (povit). The front activities were located along the line Kremenets Dytyniachi - Dubno - Pereshiv - Khromiakovo - Bohuslavka - Kulykovychi - Chortoryisk - Bilska Volya - Loknytsia. Almost immediately after the occupation by the Austrian army, the territory of Volyn district (this is the name given to these lands) became the arena of the Ukrainian public organizations activity - the Union for the Liberation of Ukraine, the Ukrainian General Council and its subdivisions.

The national awareness of the population of these areas was an important and urgent matter. A low level of a national consciousness of the local Ukrainians was recorded by numerous testimonies of the Galicians, who arrived in sub-Russian Volyn. Dmytro Vitovsky, a wellknown public figure, described the reaction of the people of Volyn to the question of who they were: "They stared at me, and some said that they were the Orthodox, the others - villagers, the others - masters, these - "peasants", those - "the Russians", and only one said - "malorosy" (Vitovskyi, 2002). So, as another Sich riflemen, Hnat Martynets, summed up, "The population is oppressed, tired, subdued and ignorant. There is one fun that the local population doesn't call itself Muscovites. In short, a sad fate, and perhaps, only because we have long called ourselves "the Rusyns". The only thing that hurts us is that everyone is afraid that he is a faithful son of our monarch, and is called a Ukrainian". There is no coincidence that Ulas Samchuk much later characterized Volyn as "one that was Russified on the top and illiterate at the bottom, indistinct, "local", "khokhlatsko-malorosiyska" (Samchuk, 1977 - 1978).

In 1916, the Ukrainians of Galicia took advantage of the opportunity to spread the national idea and educational activities (primarily through the opening of Ukrainian schools). The military conditions dictated the need to take the main burden of this issue on the shoulders of the Sich riflemen. In the educational work, members of the USS collaborated with the Union for the Liberation of Ukraine, the Bureau of Cultural Aid. However, it should be understood that without the support of the entire Ukrainian community, their efforts would have been in vain. Large material donations, which were collected in Galicia under the slogan "For Volyn Schools", testified to the real interest and support of the Galician Ukrainians in the cultural and educational activities in Volyn (as well as, after all, in Transcarpathia).

It is worth mentioning that initially the Austro-Hungarian authorities gave permission for the activity of three recruiting commissioners in Volyn. They were: Dmytro Vitovsky 
in Kovel, Mykola Saevych in Volodymyr-Volynsky, Mykhailo Havrylko in Lutsk. Only owing to their hard work, the first achievements in recruiting volunteers to the USS Legion, convincing the dependence on national awareness was it possible to increase the presence of riflemen in Volyn. "With great effort, convenience and struggle, we later managed to call many intelligent riflemen to Volyn. Ukrainian schools grew here like mushrooms after rain. Our riflemen-teachers taught children at schools and owing to their activity they soon gained the trust and affection among the population, not even among the Ukrainian one. Despite the need, hunger and cold, children rushed to their native school, and treated their teachersriflemen and female-teachers the same way they treated their parents. And no matter how depressing military Volyn was, no matter how the heart pounded in the chest at the sight of ruined farms and fields with weeds - our native schools were always the healing balm that did not allow to despair and lose hope for a moment" (Stepovenko, 1918, p. 126).

The USS commissioners, who were sent to Volyn and started working under difficult conditions, deserve a special attention. Each of them was an extraordinary personality and deserves a separate story. Without their dedicated work, it would hardly be possible to get at least some results.

First of all, we should mention Dmytro Vitovsky, the person, who turned out to be an outstanding figure of the National Liberation Struggle in 1917 - 1921. D. Vitovsky (1887 1919) took care of the Ukrainian issue in Kovel region. The contemporaries characterized D. Vitovsky as a self-critical man, without any hint of ambition; only life circumstances put him on a leading position. "No one felt as accurate as he did, the one who had the feeling for the national interest and riflemen duty at the moment. And no one else could so eloquently figure the things out and convince everyone how to act. He was the conscience of the Riflemen" (Zaklynskyi, 1937, p. 67). At the same time, before leaving for Volyn the riflemen leadership was optimistic and assured the commissioners that the Austro-Hungarian command would give them a very warm welcome. D. Vitovsky was quite skeptical about such a statement, which did not particularly surprise the audience, because even then he had earned a reputation of being a "black crow" and a fierce pessimist (Zabrovarnyi, 1995, p. 249). However, the time confirmed his rightness and quite quickly, after arriving in Volyn, the riflemen were left with almost no means of existence, because there were high prices there and money literally "melted".

Particular difficulties consisted in the fact that in Kovel D. Vitovsky was almost the only representative of the Ukrainians (CSHAUL, f. 353, d. 1, c. 7, p. 7). That is why, he sadly wrote in the letter dated February 13, 1916, that knowing the situation about Havrylko and having the information about the situation with Saevych, in his opinion, he found himself in the worst position. Though gradually, D. Vitovsky succeeded in having a mutual understanding with the local population. He visited the villages, got acquainted with villargers' life, its needs, shortcomings and grievances, communicating with the peasants and spreading a national consciousness among them. "I roam through the villages like Makar in hell, I go to the village two or three times, even when there is no Wehrlustige" - he wrote to Koshovyi (Hirniak, 1937, 3, 10).

The lack of noticeable results depressed D. Vitovsky himself, and in addition, Lviv demanded him to report on the work that had been done. Being convinced that the results of his ant, but not demonstration work (as defined by I. Krypiakevych) (Andrysiak, 1932, 9) be sure to leave a mark on Volyn land, D. Vitovsky was not prone to unnecessary and loud reports. He was convinced that all this was superfluous, "because every note implies contraction, every firework confuses Galician readers, and every cry, whether of joy or pain, - is completely unnecessary, because it is unsuccessful" (Hirniak 1937, 5, 14). 
Mykola Saevych was another commissioner, who was born in Staryi Uhryniv in Galicia, near Kalush. In the editorial office of "Chervona Kalyna" there are drawings by Osyp Kurylas, on one of which Mykola Saevych is depicted. The USS member is depicted in the form of a clock, which reflects speed symbolically. He made a lot of efforts to ensure the functioning of Ukrainian schools in Volodymyr-Volynskyi, Vuykovychi, Rusnov, Byskupychi, Budiatychi, Zashkovychi and the others. M. Saevych wrote on this occasion: "Despite the need, hunger and cold, children rushed to their native school, and treated their teachers-riflemen and female-teachers the same way they treated their parents. And no matter how depressing military Volyn was, no matter how the heart pounded in the chest at the sight of ruined farms and fields with weeds - our native schools were always the healing balm that did not allow to despair and lose hope for a moment" (Stepovenko, 1918, p. 126).

Galician and Naddniprianski Ukrainian institutions provided a significant assistance in founding Ukrainian public schools. Two organizations were founded in Lviv to take care of schooling in the lands occupied by the Austria-Hungarian Empire: 1) the School Commission at the Teachers' Community, which prepared the theoretical foundations for schooling. 2) the Bureau of Cultural Aid, which dealt with a technical management. ZUR, the Union for the Liberation of Ukraine and the Bureau of Cultural Aid for the Ukrainian population of the occupied lands appealed to the Ukrainian citizens to donate to Volyn schools because of a difficult financial situation of Volyn Ukrainians (monetary donations were transferred to "the book Part 9888 of "the Dniester" in Lviv, Ruska Street, 20 notifying at the same time by the card of the Bureau of Cultural Aid, Lviv, Bliakharska Street, 20 P floor). In the Ukrainian magazines, in particular, in "the Bulletin of the Union for the Liberation of Ukraine" and "Ukrainische Nachrichten", "The list of donators to Volyn Schools" was published regularly.

The head of the Bureau of Cultural Aid, which was founded in August 1915, became I. Krypiakevych, a famous historian, who proved to be a talented organizer in this position. He announced the beginning of his activity in the letter to Volodymyr Doroshenko, dated September 10, 1915. I. Krypiakevych developed a special questionnaire for representatives of recruitment commissariats on conducting cultural and educational work among Volyn Ukrainians. At the same time, special attention was paid to the establishment of a whole network of the Ukrainian public schools. The best way to succeed in this issue, he considered the creation of school committees of the three most conscious local residents and the submission of petitions to the district command with a request to organize the school with Ukrainian as the language of teaching and the study of German, because such educational establishments caused the least objection from the Austrian authorities. Due to the difficult and uncertain situation in Volyn, there should have been as many such submissions as possible in order to get ahead of the Poles in this issue. As it turned out, this remark was quite correct, as evidenced, in particular, by the school case in the village of Sukhodoly, where the school with Polish as the language of teaching was established. According to M. Saevych, this happened due to the failure to submit a permit for the opening of a Ukrainian school in the areas with a mixed ethnic composition.

It is no coincidence that after the Union for the Liberation of Ukraine ceased its activities and at the same time the Bureau of Cultural Aid for the Occupied Lands was liquidated, the issue of Ukrainian schooling in Volyn was under threat. In the diary of the Ukrainian public school of Volodymyr-Volynsky in early September of 1918 there is the following entry: "From the time the school was founded until now, the school was maintained by the Bureau of Cultural Aid for the occupied lands of Volyn and Kholmshchyna. <... Now our 
schools are in a very difficult situation: the Union for the Liberation of Ukraine has been dissolved, and at the same time the Bureau of Cultural Aid has ceased its activities. The funds of the Bureau of Cultural Aid, which remained for school purposes, are such that they can suffice to meet the most urgent needs of the still functioning schools for barely $1-2$ months". The intensity of the development of Ukrainian schooling in Volyn is illustrated in the table compiled by I. Krypiakevych.

VOLYN SCHOOLS (AUGUST 15, 1916)

Table

\begin{tabular}{|c|c|c|c|c|c|c|c|c|c|c|c|}
\hline \multirow[b]{2}{*}{ DISTRICT } & \multicolumn{4}{|c|}{$\begin{array}{l}\text { QUANTITY } \\
\text { OF SCHOOL }\end{array}$} & \multirow[b]{2}{*}{ 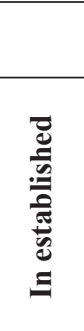 } & \multirow[b]{2}{*}{ 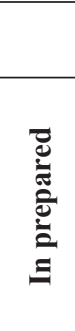 } & \multirow[b]{2}{*}{ 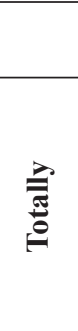 } & \multirow[b]{2}{*}{$\begin{array}{l}\stackrel{0}{\tilde{J}} \\
\stackrel{\Xi}{\Xi}\end{array}$} & \multirow[b]{2}{*}{ 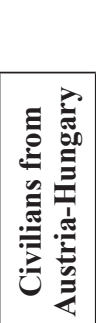 } & \multirow[b]{2}{*}{ 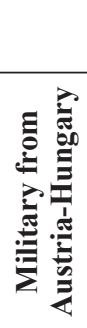 } & \multirow[b]{2}{*}{ 롤 } \\
\hline & 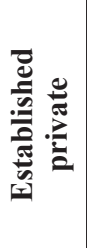 & 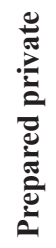 & 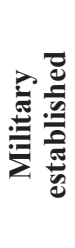 & 离 & & & & & & & \\
\hline Volodymyr & 8 & 17 & - & 25 & 735 & 628 & 1365 & 14 & 3 & - & 17 \\
\hline Lutsk & 2 & 5 & 9 & 16 & 450 & 600 & 1050 & 4 & 1 & 9 & 14 \\
\hline Kovel & 3 & 10 & 1 & 14 & 234 & 500 & 734 & 1 & - & 3 & 4 \\
\hline Dubno & - & - & 1 & 1 & 80 & - & 80 & - & - & 1 & 1 \\
\hline Kreminets & - & - & 5 & 5 & 284 & - & 284 & - & - & 5 & 5 \\
\hline Totally & 13 & 32 & 16 & 61 & 1785 & 1728 & 3513 & 19 & 4 & 18 & 41 \\
\hline
\end{tabular}

The fact should be taken into account that these results were achieved under work conditions, which Krypiakevych described as follows: “... it (work) passed with passion and zeal, violently and widely, interrupted triumphantly between Skillley of distrust of the Austrian occupying power and Charybdis of Volyn peasant's ignorance, and the work left the first grain of a national awareness in a quiet Volyn side" (I.K., 1932, 18).

A significant part of the school success in Volodymyr-Volynskyi belongs to its head master - Savyna Sydorovych. S. Sydorovych was born on April 5, 1895 in the town of Monastyryske (nowadays - a district centre in Ternopil region). Her parents Osyp Sydorovych and Anna from the Lazarevych family came from the same town. Her grandfather, Teodor Sydorovych, was an artist, his profession was mastered by Savyna's father, Osyp, who painted a number of churches in the villages and towns of Galicia - modern Ternopil region, Lviv region, Ivano-Frankivsk region and in the churches of the villages on the outskirts of Przemyśl (nowadays - the Republic of Poland). Her sister Maria became the wife of Ivan Krypiakevych. Unfortunately, a significant part of the grandfather's and father's works of art burned during the war in 1914, when the Sydorovych family house burned down completely.

In 1902 - 1905 S. Sydorovych went to the public (primary) school in Monastyryske, in 1905 - 1906 - "school of exercises" at the state ("imperial-royal") teacher women's gymnasium, in 1906 - 1910 - the Sisters Vasylianky gymnasium, in 1910 - 1914 she studied in the teacher's seminary of the Ukrainian Pedagogical Society. In 1914 she passed the maturity exam in the seminary. During different years S. Sydorovych's teachers were such well-known Galician teachers as Fr. Spyrydon Karhut, prof. Ostap Makarushka, prof. Leshchiy, I. Sitnytsky and the others. 
During the period of studying at the Sisters Vasylianky gymnasium, she made friends with Iryna Hnatiuk, Volodymyr Hnatiuk's daughter. S. Sydorovych visited the house of the Hnatiuks family, who lived in T. Shevchenko street (nowadays - Vynnychenko street, 26). S. Sydorovych visited them during summer vacations in the Carpathians. The contacts with the family of the outstanding scientist had an impact on the formation of S. Sydorovych's personality. In 1915 - 1916 she worked in the NISh library and, on the instructions of V. Hnatiuk, she organized the Society's archives, which were destroyed by the war and the Russian occupation.

The period of S. Sydorovych's studying in Lviv was difficult: the Ukrainian youth had to determine their position concerning the events, which were taking place and the onset of which was expected. The community of Galicia self-organized actively - already in 1911 "Plast" was formed. In 1913 K. Trylovsky approved the charter of "Sich Riflemen", the number of organizational centers (groups) of "Sokil", "Sich", "Plast" structures reached significant proportions on the eve of the war. S. Sydorovych was an active member of "Sokil", which is confirmed, among other things, by a group photo of the Sokil movement of 1912. S. Sydorovych organized Plast structures actively, what senior Plast members mentioned about in their memoirs; she worked in the section of female students of the Ukrainian Pedagogical Society (sanitary courses, fundraising for the needs of the created legion of the Ukrainian Sich Riflemen).

The name of Savyna Sydorovych occupied a worthy place among the female teachers, headed by Konstantyna Malytska at that time. The female teachers led the military patriotic movement among the cohorts of our national heroines - Olena Stepanivna, Sofia Haliechko, Pavlyna Mykhailyshyn, Hanna Dmyterko. Among those names the name of Savyna Sydorovych occupied a worthy place. Unlike her friends, she did not wear a military uniform and did not take up arms. But her life's feat in raising the Ukrainian spirit in Volyn, where it had been successfully trampled by the Russian tsar for centuries, is also surprising.

Here are some testimonies of contemporaries about the activities of a Ukrainian teacher in Volyn. "The first person we brought from Galicia was Mrs. Savyna Sydorovych, a young, talented and outstanding person, - Hnat Martynets wrote later. Her education far surpassed that of ordinary teachers, she had an extraordinary organizational and pedagogical talent and the ability not only to unite people, but also to maintain their respect both for the Ukrainian issue and for her authority". Further he pointed out that this intelligent, elegant, beautiful woman was an exceptionally industrious, diligent and hard-working person, who was engaged not only in education, but also in cultural and educational work among the public, to whom she devoted all her time. As a result, she quickly gained the love and respect not only of the Galicians, but also of the local Ukrainians. People, describing the dedicated work of S. Sydorovych, said: "She is so busy with school work and so passionate about all matters related to the people's organization that she does not think about anything else. For her, the material side of her mission is completely indifferent". It is no coincidence that Ye. Cheranovsky believed that if there had been an adequate number of such people in Volyn, the region would have been secured against the Polish encroachments in a few years.

As the head master of the Ukrainian school named after T. Shevchenko in VolodymyrVolynsky, S. Sydorovych was the author of a draft report on the activities of the school, which consisted of the following items: 1 . Ancient schools in Volodymyr-Volynskyi, written by I. Krypiakevych. 2. Chronicle of the school; 3. Teachers' meeting. 4. Science plan of the Regional School Council for Galician schools in 1892. 5. Facilities, equipment: a) library for teachers; b) library for students; c) visual aids; d) equipment for physical education. 6 . Room 
for having tea. 7. Statistics on the composition of students by ethnicity, religion, age, gender, social status. 8. Money report. The draft report's purpose, in addition to informing the public about how the money, transferred to the school was spent, was also to submit a science plan for other schools, as it was difficult to obtain it under military conditions.

Despite burdensome responsibilities, S. Sydorovych carried out much-needed public activities (as mentioned in the above description by H. Martynets). Thus, in 1918, a division of Sirozhupannyks arrived in Volodymyr-Volynskyi, created from the former Ukrainian prisoners of war, formed in the Austrian camp in Freistadt. This military unit was supposed to be the part of the UNR Army, but the Austrian authorities did not allow it for a long time. At the same time, close contacts were established with the school headed by S. Sydorovych. Joint concerts were held, the Festival on January, 19 (the Orthodox religious holiday - Jordan) on the Luha river, where a military band performed the Ukrainian carols.

After the hetman's coup, when even the officers of the division were disoriented, S. Sydorovych, after visiting Lviv and learning more about the activities of Hetman P. Skoropadsky, she did everything in her power to stabilize the situation in this division.

S. Sydorovych influenced the state of the educational process in the whole region; she made reports on the improvement of schooling; she communicated with people, visiting villages and conducting educational conversations with the people of Volyn. Peasants returning from the forced evacuation to the Russian provinces had some comfort in those conversations, no matter how difficult mode of life was. Many of those, who returned to their native land lived in dugouts, but even the best suburbs of Moscow they remembered as a terrible desert, and Moscow local population was hated by them.

Many members of the intelligentsia joined the formation of a national consciousness and national cultural revival of the Ukrainians in Volyn during World War I. The Ukrainian issue would not have been so successful without intelligentsia's participation. The Galician intelligentsia played an important role in creating the Ukrainian communities, preparing a cohort of well-known public and political figures, who made many efforts to develop schooling as the most pressing problem of the Ukrainians, an integral part of all-Ukrainian socio-political life. The USS Combat Command sent Sich riflemen and officers to Volyn, who graduated from a teacher's seminary or had, at least, a gymnasium education. In Volyn district, after more than a century break, during the school year of 1916/1917 up to a hundred Ukrainian private schools were opened. This success was achieved largely due to the work of teachers from among the military members. In total, from 1916 to the beginning of 1918, $150-250$ schools with thousands of children were established in Volyn region, primarily, owing to the efforts of the USS members. Involvement of local teachers in the educational process was important for the further development of education and the Ukrainian movement in general. Having established a network of Ukrainian schools in Volyn together with the local population, the Galician intelligentsia illustrated the people of Volyn examples of dedicated work in this field.

The Conclusions. The peculiarity of the Legion of the Ukrainian Sich Riflemen was its activity not only as an armed formation on the fronts of World War I, but also as a factor in the Ukrainian national movement. One of the tasks set by the USS members was a national self-awareness both among the Sich members themselves and among the Ukrainians of the areas where the Sich Riflemen found themselves during the hostilities. The formation of a national self-awareness was facilitated by the presence of prominent intelligentsia representatives. It was owing to their efforts in 1916 - 1918 that Volyn succeeded in the cultural and educational sphere. The dedicated work of the Galicians and Naddniprianshchyna residents, such as: D. Vitovsky, M. Havrylko, M. Saevych, 
S. Sydorovych, I. Krypiakevych and the others, became the basis for the growth of the Ukrainian movement in Volyn during the interwar period and World War II.

Acknowledgments. I express sincere gratitude to all members of the editorial board for consultations provided during the preparation of the article for printing.

Funding. The author received no financial support for the research and publication of this article.

\section{BIBLIOGRAPHY}

Andrusiak, M. (1932). Proby orhanizuvannia halytsko-ukrainskoho narodnoho viiska v 1848 1849 [Attempts to organize the Galician-Ukrainian People's Army in 1848 - 1849]. Litopys Chervonoi Kalyny - Chronicle in the Red Viburnum, (3), 9-13. [in Ukrainian]

Bahrii, M. A. (2018). Osvitno-kulturna ta prosvitnytska diialnist ukrainskoho sichovoho striletstva u Zakhidnii Ukraini [Educational, cultural and educational activities of the Ukrainian Sich Rifles in Western Ukraine]. Social Work and Education, 5 (3), 49-56. [in Ukrainian]

Bashniak, L. I. (2009). Kulturno-osvitnia diialnist u Lehioni USS (1914 - 1918 rr.) [Cultural and educational activities in the USS Legion (1914-1918)]. Visnyk Kyivskoho natsionalnoho universytetu kultury i mystetstv. Mystetstvoznavstvo - Bulletin of Kyiv National University of Culture and Arts. Art History, (21), 9-14. [in Ukrainian]

Bernadskyi, B. V. (1995). Vklad Sichovykh Striltsiv u rozvytok natsionalnoi osvity na Volyni [The contribution of the Sich Riflemen to the development of national education in Volyn]. Zbirnyk navchalnometodychnykh materialiv i naukovykh statei istorychnoho fakultetu - Collection of educational and methodical materials and scientific articles of the historical faculty, (1), 63-68. [in Ukrainian]

Bernadskyi, B. V. (2012). Nezvychainyi rozvidnyk doby Pershoi svitovoi viiny (do 125-richchia Dmytra Vitovskoho) [An unusual spy of the First World War (to the 125th anniversary of Dmytro Vitovsky)]. Vojenna istoriia - Military History (4-6), 4-10. [in Ukrainian]

Demianiuk, O. Y. (2007). Kulturno-osvitnia misiia starshyn lehionu USS na Volyni [Cultural and educational mission of the officers of the USS Legion in Volyn]. In Demianiuk, O. Y. Ukrainskyi molodizhnyi rukh Zakhidnoi Ukrainy: vid zarodzhennia do borotby za ukrainsku derzhavnist [Ukrainian Youth Movement of Western Ukraine: From Origin to Struggle for Ukrainian Statehood] (pp. 133-141). Lutsk: PVD "Tverdynia".

Demianiuk, O. Y. (2015). Diialnist Ukrainskykh sichovykh striltsiv ta verbunkovykh komisariv USS na terytorii zakhidnovolynskykh povitiv [Activities of Ukrainian Sich riflemen and recruiting commissioners of the USS on the territory of West Volyn counties.]. In Demianiuk, O. Y., Pasiuk I. Voienna istoriia Volyni: istorychni narysy [Military history of Volyn: historical essays] (in 5 vol., Vol. 3: 1914 - 1923, pp. 38-49). Lutsk: PP Ivaniuk V. P. [in Ukrainian]

Demianiuk, O. Y. (2017). Utverdzhennia narodnykh shkil na Volyni u 1916 - 1918 rr. [Approval of public schools in Volyn in 1916 - 1918]. Natsionalna osvita v stratehiiakh sotsiokulturnoho vyboru: teoriia, metodolohiia, praktyka: materialy II Mizhnarodnoi nauk.-prakt. Konferentsii [National education in strategies of socio-cultural choice: theory, methodology, practice: materials of the II International scientific-practical. conference] (pp. 99-102). Lutsk. [in Ukrainian]

Fabryka, R. (1998). Mykola Saievych - podvydnyk ridnoho slova, sichovyi strilets, prosvitytel [Mykola Saevych is an instigator of the native language, a Sich archer, and an educator]. In V. Herman (Comp., ed.). "Prosvita": istoriia ta suchasnist (1868 - 1998): Zbirnyk materialiv ta dokumentiv, prysviachenykh 130-richchiu VUT "Prosvita" im. Tarasa Shevchenka ["Education": history and modernity (1868 - 1998): Collection of materials and documents dedicated to the 130th anniversary of VUT "Education" them. Taras Shevchenko]. (pp. 148-150). Kyiv: Vydavnychyi tsentr "Prosvita", Vydavnytstvo "Veselka". [in Ukrainian]

I. K. (1932). USS u Volodymyri 1916 - 17 rr. [USS in Volodymyr-city 1916 - 17]. Litopys Chervonoi Kalyny - Chronicle in the Red Viburnum, (5), 18-21. [in Ukrainian]

Haidukevych, H. (2005). Osvitianska misiia prykarpatskykh Sichovykh striltsiv na Volyni v 1916 - 1917 rr. [Educational mission of the Carpathian Sich riflemen in Volhynia in 1916 - 1917]. Kraieznavets Prykarpattia - Local historian of Prykarpattia, (6), 41-42. [in Ukrainian] 
Hirniak, N. (Comp.) (1937). Z lystiv polk. Dmytra Vitovskogo [From the Letters of Dmitry Vitovskyj]. Litopys Chervonoi Kalyny - Chronicle in the Red Viburnum, (3), 9-11; (5), 13-16. [in Ukrainian]

Kalishchuk, O. M. (2000). Kulturno-osvitnia diialnist Ukrainskykh sichovykh striltsiv na Volyni: arkheohrafia pytannia[Cultural and educational activities of Ukrainian Sich riflemen in Volyn: archeography of the issue]. Naukovyi visnyk Volynskoho derzhavnoho universytetu imeni Lesi Ukrainky. Istorychni nauky - Scientific Bulletin of Volyn State University named after Lesya Ukrainka. Historical Sciences, (1), 80-83. [in Ukrainian]

Kalishchuk, O. M. (2016). Ukrainski sichovi striltsi i rozbudova shkilnytstva na Volyni (1916 pochatok 1918 rr.) [Ukrainian Sich Riflemen and the Development of Schooling in Volhynia (1916 early 1918)]. In Ukrainske derzhavotvorennia: problemy i suchasnist: zb. nauk. pr. [Ukrainian state formation: problems and modernity: coll. science. works], (XII), 15-24. [in Ukrainian]

Kalishchuk, O. M. (2016). Volyn v roky Pershoi svitovoi viiny u spohadakh ususiv [Volyn during the First World War in the memories of the Usus]. Mynule $i$ suchasne Volyni ta Polissia. Persha svitova viina na Volyni ta Volynskomu Polissi: materialy 58 Mizhnarodnoi nauk. konf., prysviachenoi 100-richchiu podii Pershoi svitovoi viiny na Volyni [Past and present of Volyn and Polissya. The First World War in Volyn and Volyn Polissya: materials 58 of the International Science. conference dedicated to the 100th anniversary of the First World War in Volyn]. Lutsk. [in Ukrainian]

Klymenko, N. P. (2007). Ivan Krypiakevych: kulturno-prosvitnytska diialnist na Volyni ta Kholmshchyni pid chas Pershoi svitovoi viiny [Ivan Krypyakevych: cultural and educational activities in Volyn and Kholmshchyna during the World War I]. In Samoilenko, H. V. (Comp.). Literatura ta kultura Polissia - Literature and culture of Polissya. Vyp. 39: Istoriia ta kultura Polissia y Ukrainy v suchasnomu naukovomu spryiniatti [History and culture of Polissya and Ukraine in modern scientific perception], (pp. 76-87). Nizhyn: Vydavnytstvo NDU imeni M. Hoholia. [in Ukrainian]

Kuzmenko, T. H. (2005). Pedahohichna ta osvitnia diialnist Ukrainskykh sichovykh striltsiv na Volyni [Pedagogical and educational activity of Ukrainian Sich riflemen in Volyn]. Visnyk Kyivskoho natsionalnoho universytetu kultury i mystetstv - Bulletin of the Kyiv National University of Culture and Arts, (3), 11-14. [in Ukrainian]

Lazarovych, M. V. (2003). Kulturno-prosvitnytska diialnist Ukrainskykh sichovykh striltsiv u roky Pershoi svitovoi viiny [Cultural and educational activities of Ukrainian Sich riflemen during the First World War]. Ternopil: Taip, 114 p. [in Ukrainian]

Lazarovych, M. V. (2016). Humanitarna ta prosvitnytska diialnist Ukrainskykh sichovykh striltsiv na Volyni (1916 - pochatok 1918 r.) [Humanitarian and educational activities of the Ukrainian Sich Riflemen in Volyn (1916 - early 1918)]. Naukovyi visnyk Skhidnoievropeiskoho natsionalnoho universytetu imeni Lesi Ukrainky. Istorychni nauky - Scientific Bulletin of the Lesia Ukrainka East European National University. Historical Sciences, (3), 16-22. [in Ukrainian]

Lazarovych, M. V. (2016). Lehion Ukrainskykh sichovykh striltsiv: formuvannia, ideia, borotba [Legion of Ukrainian Sich Riflemen: formation, idea, struggle]. Ternopil: Dzhura, 628 p. [in Ukrainian]

Lepisevych, P. M. (2003). Kulturno-osvitni aktsii Zahalnoi Ukrainskoi Rady na Kholmshchyni ta Volyni (1915 - 1916 rr.) [Cultural and educational actions of the General Ukrainian Council in Kholmshchyna and Volyn (1915 - 1916)]. Zbirnyk navchalno-metodychnykh materialiv i naukovykh statei istorychnoho fakultetu VDU - Collection of educational and methodical materials and scientific articles of the historical faculty of VSU, (8), 34-40. [in Ukrainian]

Lytvyn, M. R. \& Naumenko, K. (1990). Istoriia halytskoho striletstva [History of Galician shooting]. Lviv: Kameniar, 200 p. [in Ukrainian]

Pater, I. H. (1996). Kulturno-osvitnii rukh na Volyni, Kholmshchyni i Pidliashshi v chasy svitovoi viiny [Cultural and educational movement in Volhynia, Kholm and Podlasie during the World War]. Teoretychni ta orhanizatsiini problemy formuvannia repertuaru ukrainskoi knyhy ta periodyky: dopovidi ta povidomlennia Mizhnarodnoi naukovoi konferentsii [Theoretical and organizational problems of forming the repertoire of Ukrainian books and periodicals: reports and announcements of the International Scientific Conference] (pp. 241-232). Lviv. [in Ukrainian]

Pater, I. H. (1998). Soiuz vyzvolennia Ukrainy i natsionalne vidrodzhennia na Volyni ta Polissi (1915 - 1918 rr.) [Union for the Liberation of Ukraine and national revival in Volyn and Polissya 
(1915 - 1918)]. Mynule i suchasne Volyni: Oleksandr Tsynkalovskyi i krai: materialy IX naukovoi ist.kraiezn. mizhnar. Konf. [Past and present of Volyn: Alexander Tsinkalovsky and the region: materials of the IX scientific ist.-kraezn. international conf] (pp. 226-229). Lutsk. [in Ukrainian]

Reient, O. P. (2016). Persha svitova viina: heopolitychna stratehiia ta znachennia dlia Ukrainy [World War I: geopolitical strategy and significance for Ukraine]. In Troian, S. S. (Ed.). Persha u fokusi istorii (dyplomatychni ta politychni kolizii Velykoi viiny) [The first in the focus of history (diplomatic and political conflicts of the Great War)] (pp. 165-189). Kyiv: Kondor-Vydavnytstvo.

Rozhak-Lytvynenko, K. B. (2017). Mystetske uhrupovannia Ukrainskykh sichovykh striltsiv: khudozhnyky, tradytsii, zhanrovi ta stylovi osoblyvosti tvoriv [Artistic group of Ukrainian Sich shooters: artists, traditions, genre and stylistic features of works] (Candidate's thesis). Lviv. [in Ukrainian]

Rudenko, O. V. (2017). Kulturolohichnyi aspekt osvitnoi diialnosti Savyny Sydorovych [Culturological aspect of Savina Sidorovych's educational activity]. Visnyk Zakarpatskoi akademii mystetstv - Bulletin of the Transcarpathian Academy of Arts, (9), 117-121. [in Ukrainian]

Samchuk, U. O. (1977 - 1978). Volyn nezabutnia. Slovo do yuvileiu 25-richchia Instytutu doslidiv Volyni u Vinnipezi (25.5.1977) [Volyn is unforgettable. A word on the anniversary of the 25th anniversary of the Volyn Research Institute in Winnipeg (May 25, 1977)]. Litopys Volyni-Chronicle of Volhynia, (12), 15-25. [in Ukrainian]

Soloviov, O. M. \& Soloviov, S. O. (1996). USS na Volyni (1914 - 1917 rr.) [USS in Volyn (1914 1917)]. Naukovyi visnyk Volynskoho derzhavnoho universytetu imeni Lesi Ukrainky. Istorychni naukyScientific Bulletin of Volyn State University named after Lesya Ukrainka. Historical Sciences, (3), 99-104.

Stepovenko, M. (1918). "Ukrainski sichovi striltsi" na Volyni ["Ukrainian Sich Riflemen" in Volyn)]. Chervona Kalyna: Literaturnyi zbirnyk "Ukrainskoho Sichovoho Viiska" - Chervona Kalyna: Literary Collection of the Ukrainian Sich Army (pp. 118-126). Lviv: Chervona Kalyna. [in Ukrainian]

Tsentralnyi derzhavnyi istorychnyi arkhiv Ukrainy, m. Lviv (CSHAUL - Central State Historical Archives of Ukraine in Lviv)

Velykochyi, V. S. (2012). Ukrainske sichove striletstvo u voienno-revoliutsiinu dobu 1914 - 1919 rr. yak obiekt doslidzhen natsionalnoi istoriohrafii: shtrykhy do zahalnoi kharakterystyky [Ukrainian Sich shooting in the military-revolutionary period of $1914-1919$ as an object of research in national historiography: touches to the general characteristics]. Karpatskyi krai-Carpathian region, (2), 18-25. [in Ukrainian]

Vitovskyi, D. (2002). Volynskyi zapysnyk [Volyn notebook]. Lviv: Vydavnychyi tsentr LNU, 64 p. [in Ukrainian]

Zabrovarnyi, B. Y. \& Bernadskyi, B. V. (1996). Shtrykh do portreta Dm. Vitovskoho [Touch to the portrait of Dm. Vitovsky] In Dubyna, M. I., Oliander, L. K. (Comp.). "Rode nash krasnyi...": Volyn u doliakh kraian i liudskykh dokumentakh ["Our Red Kind...": Volyn in the fate of the region and human documents] (in 3 vol., Vol. 1, pp. 248-250). Lutsk: Vezha. [in Ukrainian]

Zaklynskyi, M. (1937). Vitovskyi yak politychnyi providnyk Striletstva v 1917 r. [Vitovsky as a political leader of the Riflemen in 1917]. Kalendar Chervonoi Kalyny na 1937 r.-Calendar of the Red Viburnum for 1937. Lviv, 67 p. [in Ukrainian]

The article was received on February 17, 2020. Article recommended for publishing 26/11/2020. 